\title{
High Fluoride, Modest Fluorosis: Investigation in Drinking Water Supply in Halaba (SNNPR, Ethiopia)
}

\author{
Frank van Steenbergen ${ }^{1}$, Redda Tekle Haimanot ${ }^{2}$, Aschalew Sidelil ${ }^{3}$ \\ MetaMeta, Paardskerkhofweg, AJ'sHertogenbosch, The Netherlands \\ E-mail: fvansteenbergen@metameta.nl,redda@ethionet.et, a.sidelil@rippleethiopia.org \\ Received April 6, 2010; revised September 21, 2010; accepted December 8, 2010
}

\begin{abstract}
In Halaba district in Southern Ethiopia fluoride levels from boreholes are high (2.6 to $7.0 \mathrm{mg} / \mathrm{l}$ ), yet the incidence of fluorosis is modest. Drinking water users living in the vicinity of four drinking water systems that have been in operation for more than 35 years were surveyed. Out of 625 persons 5 percent had severe dental fluorosis and 42 percent had mild forms - which is considerably less than results of other areas with comparable fluoride levels. The incidence was highest in the older age groups. Possible explanations were explored. A likely reason may be the continued large dependence on rain water harvesting ponds for human consumption alongside the use of water from the public borehole systems, but more investigations would be required to confirm this proposition.
\end{abstract}

Keywords: Ethiopia, Fluoride, Fluorosis, Rift Valley, Water, Health

\section{Introduction}

This paper presents the results of an investigation into the prevalence of fluorosis in Halaba special woreda (district) in SNNPR (Southern Nations, Nationalities and People's Region) in Ethiopia. The interest in Halaba comes from the comparatively low fluorosis levels in the district, even though Halaba is located in the high fluoride Rift Valley belt. This paper aims to establish the low incidence of fluorosis and explore likely causes and make a link to on-going policy discussions on the mitigation of fluorosis in Ethiopia.

Fluorosis is assessed as a risk for a population of close to 8.5 Million in Ethiopia. The population at risk lives mainly in the Rift Valley—spread over different regional states: Afar, Amhara, Oromia and SNNPR. Moreover, there is an influx of migrants into this potentially rich part of the country. In the absence of rivers in large part of the area, communities largely depend either on rainwater harvesting ponds or increasingly on groundwater from public boreholes for their drinking water supply. The boreholes brings water that is relatively free from

\footnotetext{
${ }^{1}$ MetaMeta Research (www.metameta.nl)

${ }^{2}$ Grarbet Tehadiso Mahber

${ }^{3}$ RiPPLE (www.rippleethiopia.org)
}

bacteriological contamination, but at the same time the use of borehole water increases the risk of fluorosis, as fluoride levels are high.

A number of surveys have established high fluoride levels in the Ethiopian Rift Valley. An earlier survey with data collected from 270 water resources established that 35 percent of all sources had fluoride levels in excess of $5 \mathrm{mg} / \mathrm{l}$ [1]. A more recent extensive survey-involving 1438 samples-established that 50 percent of deep wells and 26 percent shallow wells ${ }^{4}$ of the Rift Valley yield fluoride levels above $1.5 \mathrm{mg} / \mathrm{l}$ and respectively 12 percent and 6 percent values above $7 \mathrm{mg} / \mathrm{l}$. Outside the Rift only 4 percent and 5 percent of deep and shallow wells respectively have fluoride level above 1.5 $\mathrm{mg} / \mathrm{l}$ [2]. The main area with high fluoride levels outside the Rift Valley is the area around Jimma in the west of the country.

Fluorosis has significant socio-economic impacts. The aesthetic problems related to dental fluorosis and the psychological impact are hard to quantify yet should not be underestimated-especially among young people. Moreover, persons who develop skeletal fluorosis suffer considerable hardship and have reduced productivity.

\footnotetext{
${ }^{4}$ Deep wells are defined as wells with a static water level above 120 metres. Shallow wells fall largely in the category 30 to 120 metres.
} 
This led for instance to early retirement as is the case of the Wonji/Shoa factory workers, who were the first with whom fluorosis was diagnosed in Ethiopia in the mid-1970's. At present there is no single policy to address the fluorosis problem in Ethiopia but under the Fluorosis Mitigation Project, coordinated by the federal Ministry of Water and Energy, several initiatives are on-going to address the issue: systematic mapping and looking at a range of mitigation measures. In public drinking water systems in cities in the Rift Valley, such as Ziway, the Nalgonda method (use of aluminium sulphate and lime) is practiced. In rural areas, where the majority of the population resides, defluoridation is tried at pilot scale, either as household or community level treatment-the main techniques used being Nalgonda and bone-char. In addition in some areas regional governments are opting for safe sourcing-bringing relatively fluoride-free water from often considerable distance (for some systems in access of 30 kilometres). There is as yet no attention for safe well development as implemented elsewhere [3]. Under safe well development fluoride concentrations at different layers of the aquifer are measured and well screens are placed in layers with low concentrations or low temperatures (fluoride being less soluble at lower temperatures).

There is no official standard guideline on fluoride levels in Ethiopia though in the last ten years several organizations have adopted the WHO norm of $1.5 \mathrm{mg} / \mathrm{l}$, sand in practice have refrained from commissioning wells that have fluoride levels above this threshold value. The Government of Ethiopia is contemplating to put the threshold at $3.5 \mathrm{mg} / \mathrm{l}$-hence accepting the inevitability of a certain degree of dental fluorosis.

Halaba woreda is located in the eastern part of SNNPR at an elevation that ranges between 1,700 to 2,200 metres. The monthly mean maximum temperature in Halaba varies between 24.9 and 29.9 degrees Celsius. Monthly mean minimum temperatures are between 6.7 and 13.8 degrees Celsius. The total population of the woreda in 2006 was estimated at 222,991. Most live in rural areas (88 percent), the remainder in small towns. The woreda has a total area of 973 square kilometres.

Drinking water in Halaba comes from rivers, rain water harvesting ponds and deep borewells. The rain water harvesting ponds are usually carefully protected by communities. They are commonly fenced or surrounded by trenches - to avoid livestock transgressing. The ponds fill up in the rainy season (June to September) and store water some four months afterwards. They then dry up and in the period February-May people typically have to resort to other sources of drinking water. Being open surface bodies, used by humans and animals alike, the water in the ponds is inevitably bacteriological contaminated.
In addition to the water ponds and rivers the woreda is served by 24 deep borewells with distribution networks connecting them to water points (65 in total). In Halaba there is no shallow groundwater to tap into: groundwater levels in the boreholes are between 97 to 360 metres. 52 out of 76 Farmers Associations (kebeles) have no improved water system. Unfortunately, the deep borewells have a high failure rate: 42 percent of schemes and water points are non-functional [4]. One main factor behind the non-functionality is that it takes on average one year for the Water Resources Bureau to repair breakdowns. This is due to capacity constraints in the Water Resources Bureau. There is no other organization in the area that can provide these specialist services.

Fluoride levels in Halaba are high, as elsewhere in the Rift Valley (see Figure 1). The earlier constructed drinking water systems all have water with fluoride levels in excess of the WHO standard of $1.5 \mathrm{mg} / \mathrm{litre}$ - in fact most of the boreholes (15 out 24) provide water with more than $3.5 \mathrm{mg}$ fluoride/litre. In the last ten years there has been more attention to possible effects of high fluoride levels and in at least one case a tubewell that was drilled was closed after water quality tests established fluoride levels in excess of the WHO norm.

What is special about Halaba, however, is that though fluoride levels are high, the incidence of fluorosis appears to be modest. This was just observed by Deneke et.al [4]. Below the relation between the high fluoride level and the seemingly modest degree of fluorosis is further explored. Two issues are addressed. The first is to establish the extent of fluorosis in Halaba-concentrating on four of the longest-running systems in the district and the second is to explore several possible explanations of the relatively low occurrence of fluorosis in Halaba: dietary habits, water consumption and water quality.

\section{Research: Methodology and Results}

To explore the incidence of fluoride and fluorosis water quality samples were collected and the incidence of fluorosis was investigated among drinking water users of four of the longest-serving public drinking water facilities in Halaba: Debeso (constructed in 1959); First Mekala (1971); Qobochobare (1971) and Rokanene Tefo (1971). The four systems combined serve 58,000 people, far in excess of their original design population (see Table 1). In addition, in these locations focal group interviews discussing knowledge, attitudes and practices were held.

Fluoride levels in all twenty-four drinking water systems in Halaba are high. They range between 1.3 to 13.1 $\mathrm{mg} / \mathrm{l}$ - with the large majority of systems providing water in excess of $3.5 \mathrm{mg} / \mathrm{l}$ - the level at which the risk of the more severe skeletal form of fluorosis, becomes high 


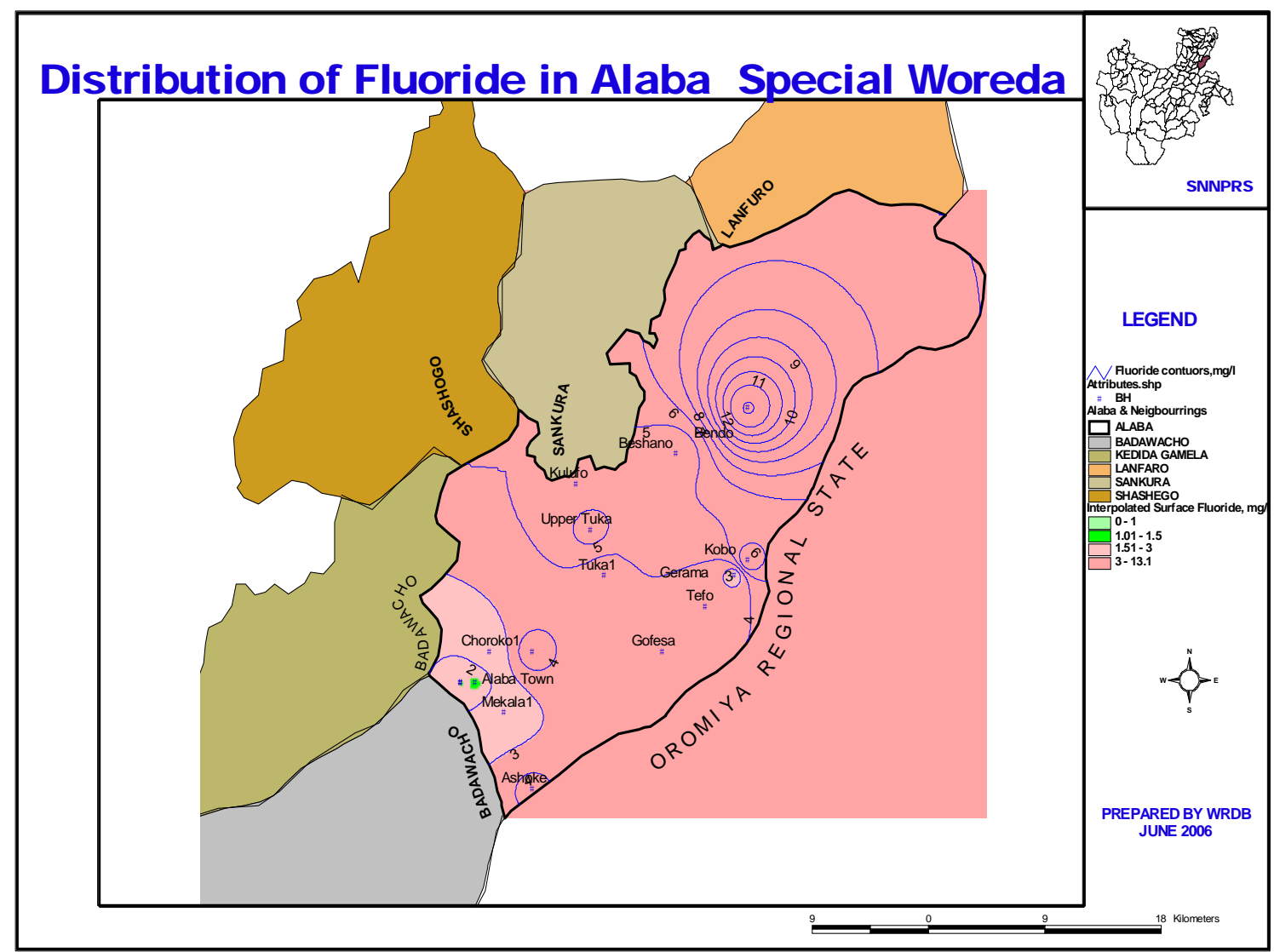

Source: Water Resources Bureau SNNPR

Figure 1. Fluoride level in Halaba in mg/litre.

(see annex 1).

Table 1 gives a number of basic facts on the four systems. As elsewhere in the district fluoride levels in these four drinking water systems in Halaba are high: between 2.6 to $7.0 \mathrm{mg} / \mathrm{l}$.

In the service area of all these four systems the incidence of fluorosis was investigated. A survey was done among 625 water users of these four systems-consisting of a visual inspection of dental fluorosis. Photographs were taken and compared with the TSIF (Tooth Surface Index of Fluorosis) ${ }^{5}$. No fluorosis, light fluorosis and severe fluorosis correspond respectively with score 0 ; score 1-3 and score 4-8 of this index.

Out of 625 persons only 12 (5 percent) had severe dental fluorosis (whole teeth are changed to reddish brown colour) - mainly in the older age brackets (above 30 years). This is related to a longer exposure. 42 Percent of the sample population had a light form of dental fluorosis: little or dotted spots on the teeth. The majority of people appeared to be free of symptoms of fluorosis. Table 2 is a summary of the survey results. None of the

${ }^{5}$ TSIF (Tooth Surface Index of Fluorosis): Horowitz et al. (1984), quoted in [5]
625 persons surveyed suffered from skeletal fluorosis.

Also in the perception of people fluorosis is not singled out as a major health issue-unlike diarrhea, dysentery and malaria. The link between teeth disfigurations and fluorosis is generally not made. The dental deformations are seen to be caused by "mich", which is a disorder perceived to be associated with the exposure to sunlight after the intake of spicy food.

The modest incidence of fluorosis in Halaba deviates from findings of other studies in Ethiopia and East Africa [6]. Sampled 306 children aged 12-15 years in villages in another part of the Ethiopian Rift Valley (i.e. Matahara) and found that in areas with moderate fluoride-levels (0.3-2.2 mg/l) i.e. substantially lower than Halaba-the percentage of children having light affection ${ }^{6}$ was 80 percent and having a severe affection 11 percent. In villages with very high fluoride levels $(10-14 \mathrm{mg} / \mathrm{l})$ the percentage of lightly and severely affected were respectively 40 percent and 60 percent. Another case study concerns the area around Lake Elementatia in Kenya. In the Lake Elementatia area fluoride levels ranged between

${ }^{6}$ Lightly affected defined as TF (Thylstrup-Fejerskov Index) values 1-4 and severely affected as TF values 5-7. 
Table 1. Basic parameters of four drinking water systems.

\begin{tabular}{lcccccc}
\hline & $\begin{array}{c}\text { Year of } \\
\text { construction }\end{array}$ & $\begin{array}{c}\text { Design } \\
\text { population }\end{array}$ & $\begin{array}{c}\text { Actual } \\
\text { population }\end{array}$ & $\begin{array}{c}\text { Capacity } \\
(\mathrm{l} / \mathrm{s})\end{array}$ & $\begin{array}{c}\text { Depth } \\
(\mathrm{m})\end{array}$ & $\begin{array}{c}\text { Fluoride } \\
(\mathrm{mg} / \mathrm{l})\end{array}$ \\
\hline Rokanene Tefo & 1971 & 2854 & 8829 & 2.6 & 216 & $6.7-7.0$ \\
Qobochobare & 1971 & 3991 & 16235 & 2.2 & 254 & $3.4-4.4$ \\
First Mekala & 1971 & 2167 & 21501 & 5 & 174 & $2.6-3.8$ \\
Debeso & 1959 & 1280 & 12016 & 3 & 318 & 3.9 \\
\hline
\end{tabular}

Table 2. Indication of fluorosis in service areas of four water supply systems.

\begin{tabular}{lccccc}
\hline \multirow{2}{*}{ Water supply system } & \multirow{2}{*}{ Age bracket } & \multicolumn{3}{c}{ Incidence of Fluorosis } & \multirow{2}{*}{ Total } \\
\cline { 2 - 4 } Rokanene Tefo & $0-15$ & Normal & Light & Severe & 51 \\
& $16-30$ & 33 & 18 & 0 & 51 \\
Total & $>30$ & 26 & 24 & 3 & 51 \\
Qobochobare & & 11 & 78 & 5 & 153 \\
& $0-15$ & 70 & 14 & 0 & 51 \\
Total & $16-30$ & 37 & 29 & 0 & 51 \\
First Mekala & $>30$ & 22 & 19 & 6 & 53 \\
& & 28 & 62 & 155 \\
Total & $0-15$ & 87 & 15 & 0 & 54 \\
Debeso & $16-30$ & 39 & 22 & 1 & 54 \\
& $>30$ & 32 & 18 & 1 & 54 \\
Total & & 35 & 55 & 0 & 162 \\
Grand total & $0-15$ & 106 & 7 & 0 & 53 \\
Grand total ( percent) & $16-30$ & 46 & 29 & 0 & 52 \\
& $>30$ & 23 & 33 & 0 & 50 \\
\end{tabular}

2.1 and $20.1 \mathrm{mg} / \mathrm{l}$, and again the incidence of fluorosis was much higher than in Halaba-96 percent among children up to age 14 [7].

\section{Discussion}

The question is: what may explain this relatively low incidence of fluorosis in Halaba? Often the relatively moderate levels of fluorosis are associated with water and food habits, in particular:

- Water intake. In high temperature areas for instance drinking water consumption is higher and so are the intake of fluoride and the risk of fluorosis.

- Diets. For instance the intake of substantial quantities of calcium through milk and the consumption of non-animal protein has been suggested to reduce the incidence of fluorosis.

In Halaba water and food habits were discussed in focus group interviews in the service areas of the four drinking water schemes. The focus group results on water and food intake are similar between the four areas and appear representative for the entire woreda:
Water consumption in Halaba was assessed on the basis of jerry cans filled and used. From this it appears that water intake is less than the recommended quantity. Average use is 10 litres per capita/day — of which 3 litre per capita is consumed for drinking water and food preparation. However, what is striking is the strong reliance on rainwater ponds. Even in the areas served by the water supply systems, people continue to make intensive use of water collected in surface water ponds. Pond water use is intensive for 7-8 months a year-during and shortly after the rainy season, i.e. as long as the ponds last. The main reason for the preference for ponds is the money that can be saved by not having to pay the water charges from the borehole systems. According to focus group interviews in the four localities pond water is used for cooking purposes, whereas drinking water usually comes from the borewells. This means however that at least 40-50 percent of the human consumption of water in Halaba comes from the drinking water ponds still.

Food habits were assessed as well in the focus group discussions. The most important staples in Halaba are in order of importance: sorghum, finger millet, sorghum 
and teff, prepared as standard bread or the traditional pancake-like unleavened bread known in Ethiopia as enjera. In addition boiled haricot beans are also commonly eaten. The most common vegetables are cabbage and potatoes. In Halaba milk and diary products (butter, yoghurt) are part of the diet, but are not consumed in large quantities. In almost all villages the chewing of chat (qat edulensis) is common. Teeth are cleaned by sticks cut out of branches of olive wood or other trees. The food habits in Halaba are not remarkably different from other areas in this part of Ethiopia and the diet factor on first sight does not appear to explain the low incidence of fluorosis. There is relatively little intake of animal protein in Halaba, however, that may be part of the explanation. In other areas different food habits among Christian (limited meat consumption) and Muslim (higher meat consumption) have been correlated with a relatively below and above average incidence of fluorosis (Deverill, pers. comm.).

A third explanation for the low incidence of fluorosis may be in the overall composition of the water-the possible presence of other elements that compensate the impact of fluoride. The general consensus is that this cannot be an explanation, but the results are attached as annex 2-for further discussion.

In summary, the study established that in spite of running high fluoride drinking water systems, the occurrence of fluorosis among the users of these drinking water systems is modest in Halaba. Fluorosis does not figure in the list of reasons for morbidity. Other water-related diseases do, and affect a considerable part of the population of Halaba. Among the top 10 diseases in the woreda, according to the local health departments are: intestinal parasites; skin infections; dysentery; gastroenteritis; and amoebae. All these are directly related to the existing low coverage of safe water supply and the overall poor hygienic practices and environmental sanitation.

There are several policy implications. First the findings pose questions on the policy of not using drilled wells that have high measured levels of fluoride-as this does not seem to result in substantial health problems in Halaba. The coverage of drinking water systems is low in Halaba and people continue to partly rely on surface water ponds and rivers, that may be low in fluoride but is bacteriological contaminated. In Halaba there is therefore a serious argument in favour of using such relatively high fluoride wells and at the same time trying to improve the quality of water that is consumed from the drinking water ponds. This may be achieved by popularizing low cost 'point of use water treatment methods, such as siphon filters and colloidal silver ceramic filters. A second policy implication is the determination of water quality standards. The results from Halaba show that in spite of high fluoride levels fluorosis is not widespread, so the introduction a uniform standard for the country may not be useful. Rather than looking at fluoride levels only, it may be better instead to map the areas with high and low incidence of fluorosis and base one's interventions and priorities on that.

The study also leaves a number of research questions unanswered. The larger long-term research issue is what factors explain the low fluorosis levels. This is an area that requires more exploration. There is a need for more fact finding and discussion on this front-in particular by comparing different areas. From the food and drinking water habits the most striking finding is the large reliance of surface water, in particular the rain water harvesting ponds. More work needs to be done here and the role of drinking water ponds as a complementary source in fluoride affected areas may be better understood. In fact in another part of the Ethiopian Rift Valley (Fantale, Afar Region) there are similar observations of people preferring to use drinking water ponds, as they fear the risks of drinking high fluoride water. Another area for further study is in looking at the composition of water, and the possible affect of the overall composition of drinking water. The end results could be a more refined approach to fluorosis focussing on high fluorosis incidence areas rather than areas with high fluoride levels only, as the Halaba case indicates these are not always one and the same.

\section{References}

[1] Kloos, Helmut and T.-H. Redda, "Distribution of Fluoride and Fluorosis in Ethiopia and Prospects for Control," Tropical Medicine and International Health, Vol. 4, No. 5, 1999, pp. 355-364. doi:10.1046/j.1365-3156.1999.00405.X

[2] T.-H. Redda, Z. Melaku, H. Kloos, C. Reimann, W. Fantaye, L. Zerihun and K. Bjorvatn, "The Geographic Distribution of Fluoride in Surface and Groundwater in Ethiopia with an Emphasis on the Rift Valley," Science of the Total Environment, Vol. 367, No. 1, 2005, pp. 182190.

[3] J. J. Carrillo-Rivera, A. Cardona and W. M. Edmunds "Use of Abstraction Regime and Knowledge of Hydrogeological Conditions to Control High-Fluoride Concentration in Abstracted Groundwater: San Luis Potosí Basin, Mexico,” Journal of Hydrology, Vol. 261, 2002, pp. 2447. doi:10.1016/S0022-1694(01)00566-2

[4] Deneke, Israel and H. A. Hawassa, "The Sustainability of Water Supply Schemes: A Case Study in Halaba Special Woreda,” RiPPLE Research Report 5, 2008.

[5] Fawell, J. K. Bailey, J. Chilton, E. Dahi, L. Fewtrell and Y. Magara, "Fluoride in Drinking-Water," Geneva, WHO, 2006.

[6] Wondwossen, Fantaye, A. N. Astrøm, K. Bjorvatn and A. 
Bardsen, "The Relationship between Dental Caries and Dental Fluorosis in Areas with Moderate- and HighFluoride Drinking Water in Ethiopia," Community Dentistry and Oral Epidemiology, Vol. 32, 2004, pp. 337344. doi:10.1111/j.1600-0528.2004.00172.x
[7] R. W. Kahama, D. N. Kariuki, H. N. Kariuki and L. W. Njenga, "Fluorosis in Children and Sources of Fluoride around Lake Elementaita Region of Kenya," Fluoride, Vol. 30, No. 1, 1997, pp. 19-25.

Annex 1. Fluoride levels in Halaba drinking water systems.

\begin{tabular}{|c|c|c|c|c|c|c|}
\hline & \multirow[b]{2}{*}{ Scheme name } & \multirow[b]{2}{*}{ Year of construction } & \multirow[b]{2}{*}{ Discharge rate (1/sec.) } & \multicolumn{3}{|c|}{ Fluoride levels (mg/l) } \\
\hline & & & & Survey Water Action & $\begin{array}{c}\text { Survey SNNPR } \\
\text { Bureau/ RiPPLE }\end{array}$ & This survey \\
\hline 1 & Debeso & 1959 & 3 & & 3,9 & \\
\hline 2 & Bendo & 1984 & 3,9 & & 13,1 & \\
\hline 3 & Ajohulko & 1992 & 7,3 & & & 5,7 \\
\hline 4 & Yataoberho & 1991 & 4,9 & & & \\
\hline 5 & Felqa & 1990 & 3 & $1,3-5,5$ & & \\
\hline 6 & U/Tuqa & 1989 & 2,5 & & 5,4 & \\
\hline 7 & $1^{\text {st }}$ Tuqa & 1988 & 4,5 & & 3,4 & \\
\hline 8 & $1^{\text {st }}$ Ansha & 1976 & 2 & & & \\
\hline 9 & Hamata & 1990 & 0,5 & 3,3 & & \\
\hline 10 & $1^{\text {st }}$ Mekala & 1971 & 5 & & 2,56 & 3,8 \\
\hline 11 & $2^{\text {nd }}$ Mekala & 1986 & 3 & 2,4 & & \\
\hline 12 & Ashoka & 1989 & 4 & 2,42 & 4,22 & \\
\hline 13 & Choroqo & 1989 & 6 & & 2,45 & \\
\hline 14 & Alem Tena & 1989 & 3,5 & 1,61 & & \\
\hline 15 & Qobochobare & 1971 & 2,22 & & 7 & 6,7 \\
\hline 16 & Rokanene Tefo & 1971 & 2,6 & & 3,4 & 4,4 \\
\hline 17 & Gofessa & 1988 & 3 & & 3,17 & \\
\hline 18 & W/Gortancho & 1987 & 4,4 & & & \\
\hline 19 & Arsho & 1988 & 2,7 & & & \\
\hline 20 & Besheno & 1984 & 4,5 & & 4,25 & \\
\hline 21 & L/Lenda & 1990 & 3,8 & & 4,71 & \\
\hline 22 & Kulfo & 1988 & 4 & 2,37 & 4,6 & \\
\hline 23 & Eloloqa & 1990 & 3 & 1,84 & & \\
\hline 24 & Gerema & 1981 & 4,4 & & 2,35 & \\
\hline
\end{tabular}

Source: WaterAid (column 1); RiPPLE 2008 (column 2); RiPPLE/MetaMeta 2009 (column 3). 
Annex 2. Water quality in four selected systems.

\begin{tabular}{|c|c|c|c|c|c|}
\hline & Village & Ajohulko & First Mekala & R.Teffo & Qobo \\
\hline \multicolumn{6}{|c|}{ Unit } \\
\hline$* \mathrm{~F}^{-1}$ & $\mathrm{mg} / \mathrm{l}$ & $* 5.7$ & $* 3.8$ & $* 4.4$ & $* 6.7$ \\
\hline Total Hardness & $\mathrm{mg} / \mathrm{l}$ as $\mathrm{CaCO} 3$ & 70 & 98 & 68 & 38 \\
\hline Calcium & & 58 & 60 & 52 & 30 \\
\hline Magnesium & & 12 & 38 & 16 & 8 \\
\hline Total Alkalinity & & 472 & 337 & 416 & 442 \\
\hline Bicarbonate & & 428 & 337 & 376 & 396 \\
\hline Carbonate & & 44 & 0 & 40 & 46 \\
\hline Dissolved NH3 & $\mathrm{mg} / \mathrm{l}$ & 0 & 0.15 & 0.39 & 0.049 \\
\hline Conductivity & $\mu \mathrm{s} / \mathrm{cm}$ & 850 & 540 & 730 & 790 \\
\hline Turbidity & NTU & 0 & 2 & 0 & 0 \\
\hline Temperature & ${ }^{0} \mathrm{C}$ & 29 & 28.6 & 28.6 & 28.6 \\
\hline T.D.S & $\mathrm{mg} / \mathrm{l}$ & 430 & 270 & 370 & 400 \\
\hline Total $\mathrm{Cl}_{2}$ & $\mathrm{mg} / \mathrm{l}$ & 0.02 & 0.02 & 0.02 & 0 \\
\hline $\mathrm{PH}$ & & 8.12 & 7.92 & 8.03 & 8.22 \\
\hline \multicolumn{6}{|l|}{ Cations } \\
\hline $\mathrm{Na}^{+1}$ & $\mathrm{mg} / \mathrm{l}$ & 207 & 125 & 187 & 227 \\
\hline $\mathrm{NH}_{4}{ }^{+1}$ & $\mathrm{mg} / \mathrm{l}$ & 0 & 0.1548 & 0.4128 & 0.0516 \\
\hline $\mathrm{K}^{+1}$ & $\mathrm{mg} / \mathrm{l}$ & 12 & 8.6 & 14 & 7.8 \\
\hline $\mathrm{Ca}^{+2}$ & $\mathrm{mg} / \mathrm{l}$ & 23.2 & 24 & 20.8 & 12 \\
\hline $\mathrm{Mg}^{+2}$ & $\mathrm{mg} / \mathrm{l}$ & 2.88 & 9.12 & 3.84 & 1.92 \\
\hline $\mathrm{Fe}^{+2}$ & $\mathrm{mg} / \mathrm{l}$ & 0.05 & $* 0.45$ & 0.35 & 0.35 \\
\hline \multicolumn{6}{|l|}{ Anions } \\
\hline $\mathrm{Cl}^{-1}$ & $\mathrm{mg} / \mathrm{l}$ & 8 & 4.75 & 9 & 10.5 \\
\hline $\mathrm{NO}_{3}^{-1}$ & $\mathrm{mg} / \mathrm{l}$ & 1.0208 & 0.1452 & 0.2992 & 0.9988 \\
\hline $\mathrm{NO}_{2}^{-1}$ & $\mathrm{mg} / \mathrm{l}$ & 0 & 0.0264 & 0.0066 & 0.1749 \\
\hline $\mathrm{SO}_{4}^{-2}$ & $\mathrm{mg} / \mathrm{l}$ & 0 & 0 & 17 & 28 \\
\hline
\end{tabular}

Note: *Shows values that exceed WHO guideline values set for drinking water. 